\title{
Detection for Salt Tolerance Character in Two Selected Genotypes of Wheat
}

\author{
I. H. AL-Mishhadani Ibrahim ${ }^{1}$, Bilal F. Zakariya ${ }^{2}$, N. Ismail Eman ${ }^{1} \&$ M. Dawood Wisam² \\ ${ }^{1}$ Biotechnology Research Center, AL-Nahrain University, P. O. Box 64074, Jadriah, Baghdad, Iraq \\ ${ }^{2}$ Biology Department, AL-Razi College of Education, University of Diyala, Iraq \\ Correspondence: I. H. AL-Mishhadani Ibrahim, Biotechnology Research Center, AL-Nahrain University, P. O. \\ Box 64074, Jadriah, Baghdad, Iraq. E-mail: hassanir1955@yahoo.com
}

Received: October 3, 2014 Accepted: October 17, 2014 Online Published: November 10, 2014

doi:10.5539/ijb.v7n1p54 URL: http://dx.doi.org/10.5539/ijb.v7n1p54

\begin{abstract}
Using the genetic variation to improve salt tolerance in some wheat genotypes is a very important achievement to increase the production of salinized soils. The aim of this study is to determine the realized improvement in salt tolerance in some selected genotypes of wheat, which induced through plant breeding programs. The selected genotypes were derived from F2 populations after exposed to high salinity condition for six cycles of screening and selection. Salt tolerance of these selected genotypes $(2 \mathrm{H}, \mathrm{N} 3)$ was tested during germination, early seedling and tillering stages in salinilized soils with three salinity levels $(2,8$ and $15 \mathrm{ds} / \mathrm{m})$ as compared with the local cultivar (Tamooze-2). Results showed that all selected genotypes were significantly superior in shoots and roots growth at 8 and $15 \mathrm{ds} / \mathrm{m}$ to those of the local cultivar. At all salt levels, the highest reduction in shoots and roots growth was in the local cultivar. Results also indicated that the highest values of $\mathrm{K}^{+} / \mathrm{Na}^{+}$and ca ${ }^{+2} / \mathrm{Na}^{+}$ratios were in the selected genotypes $(2 \mathrm{H}, \mathrm{N} 3)$ at 8 and $15 \mathrm{ds} / \mathrm{m}$. therefore, significant improvement in salt tolerance was achieved in the selected genotypes through plant breeding programs. The conclusion of these results is the salt tolerance of the selected genotypes correlated with the highest values of $\mathrm{K}^{+} / \mathrm{Na}^{+}$and $\mathrm{ca}^{+2} / \mathrm{Na}^{+}$ratios in their upper leaves, then the selected genotypes were more salt tolerance than local cultivar, which had the lowest $\mathrm{K}^{+} / \mathrm{Na}^{+}$and $\mathrm{ca}^{+2} / \mathrm{Na}^{+}$ratios in upper leaves.
\end{abstract}

Keywords: plant breeding, genotypes, salinity, salt tolerance

\section{Intrduction}

Salinity is a major factor limiting plant growth and then leads to lower agriculture production in arid and semi-arid regions. Salinity in Iraq especially in middle and south caused a big reduction in the yield production of the most field crops cultivars. Damaging effects of salt accumulation in agriculture soils have influenced ancient and modern civilizations. Therefore, so tolerance to salinity stresses is a key topic to consider for crop improvement (Zohary, 1973). In irrigated agriculture, improved salt tolerance of crops can lessen the leaching requirement, and so lessen the costs of an irrigation scheme, both in the need to import fresh water and to dispose of saline water (Pitman \& Lauchli, 2002). Salt tolerant crops have a much lower leaching requirement than salt sensitive crops. In dry land agricultures improved salt tolerance can increase yield production under saline condition. When the rainfall is low and the salt remains in the subsoil, increased salt tolerance will allow plants to extract more water (Munns et al., 2006). The introduction of deep-rooted perennial species necessary to lower the water table, but salt tolerance will be required for the de-watering species and for the annual crops that follow, salt as will be left in the soil when the water - table is lowered.

Wheat is the most important crop in Iraq. One the most efficient ways to increase wheat yield under saline condition is to improve the salt tolerance in some wheat genotypes. Salt tolerance of crops may vary according to their growth stage (Mass \& Poss, 1989). In general, there are variations between growth stages of wheat plants in their salt tolerance, the most sensitive to salinity during the vegetative stage and less sensitive during the flowering and grain - filling stages (Mass \& Tiller, 1994). Therefore, the plant exposure and selection for salt tolerance under saline condition during the germination and early seedling stage are very important for improve salt tolerance in wheat plant, provided there is significant correlation between these stages and the later growth stages in their salt tolerance (AL-Mishhadani, 2012). The efficient breeding programs to overcome salinity problem by improving salt tolerant cultivars, those need information on the genetic basis of salt tolerance, genetic variation in this 
character, mode of inheritance, magnitude of gene effect, their mode of action, and $\mathrm{Na}^{+}$concentration in shoos [Gorham et al., 1990; Munns \& James, 2003; Munns et al., 2006). Also, increased salt tolerances requires new genetic sources of this character, more efficient techniques for identifying salt tolerance germplasm, and determine salt level of exposure (AL-Mishhadani, 2012). He also reported that some salt tolerant genotypes of wheat were identified through plant breeding programs. The aim of the this work is detection for salt tolerance in two wheat genotypes which selected through plant breeding programs under salinized soil condition as compared with local cultivar (Tmooze-2).

\section{Material and Methods}

The growth of the two selected wheat genotypes was examined in salinized soils experiment having treatment of 2, $8,15 \mathrm{ds} / \mathrm{m}$ as compared with local cultivar. These selected genotypes were derived from plant breeding programs after 6 cycles of exposure and selection under high salinity level $(30 \mathrm{ds} / \mathrm{m})$. Salinity levels were prepared by mixed two kind of soil that only differed in their saline degree $(\mathrm{Ec})$. The saline degree of the above levels was determined by using the electrical conductivity meter. The experiment was carried out in plastic posts, which filled with salinized soils. These pots were set up in a glasshouse in a completely randomized design with three blocks. Each pot contained one observation, the total of pots were $27(3 \times 3 \times 3 \times), 7$ seeds of each genotype were sown on each pot. All the agriculture treatments were carried out. Seeds and plants were watered with tap water (300 mill /pot) according to the field capacity. Plant of all selected genotypes and local cultivars were harvested after 4 month from the sowing date and the following characters were measured for each pot after oven drying for 3 days at $80^{\circ} \mathrm{C}$ :

1) Shoot dry weight $(\mathrm{g})$

2) Root dry weight (g)

3) $\mathrm{K}^{+} / \mathrm{Na}^{+}$ratio in upper leaves

4) $\mathrm{Ca}^{+} / \mathrm{Na}^{+}$ratio in upper leaves

The data were subjected to analysis of variance according to the experimental design.

\section{Results}

\subsection{Shoots and Roots Dry Weight (g/plant)}

There were significant differences in dry weight reduction of shoots and roots with increasing salinity level (Figures 1\&2). The dry weights of shoots and roots were more affected at $8 \& 15 \mathrm{ds} / \mathrm{m}$ than those at $2 \mathrm{ds} / \mathrm{m}$, but the reduction at $15 \mathrm{ds} / \mathrm{m}$ was higher than at $8 \mathrm{ds} / \mathrm{m}$. The growth of roots was more affected by salinity than shoot growth (Figures 1\&2) and (Plates 1\&2). The results also showed that there were significant differences between the genotypes and local cultivar in their responses to salinity. At all salinity levels, shoots and roots dry weights of the selected genotypes were less affect by salinity as compared with those of local cultivars (Figures 1\&2) and (Plates 1\&2). Also there was difference between the selected genotypes in their shoots and roots dry weights but not significant. This mean the growth of shoots and roots of the selected genotypes was proximatlly similler under salinity condition and were both higher than those of the local cultivar (Plates 1\&2).

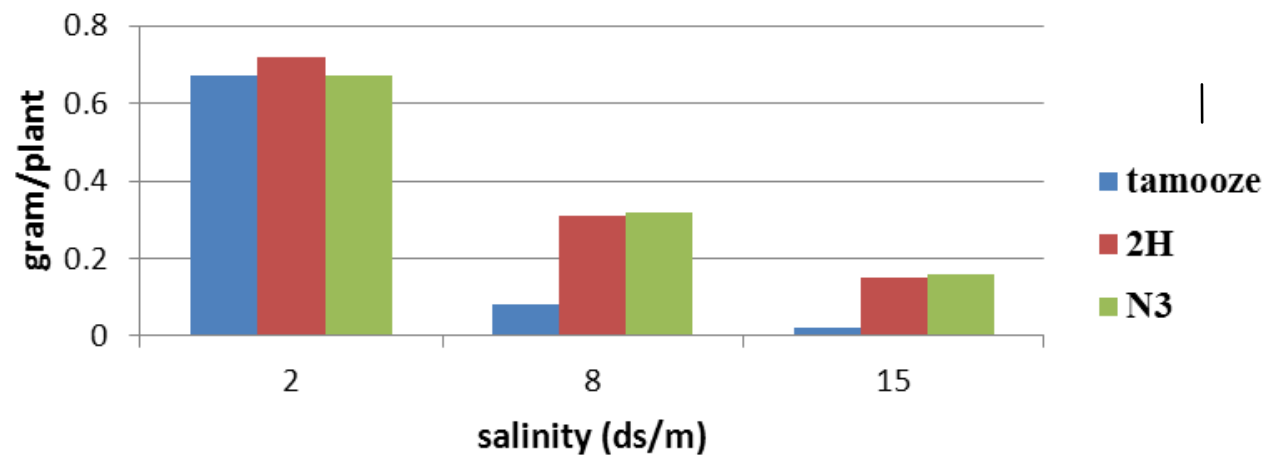

Figure 1. Shoot dry wight of selected genotypes of wheat under salinity condition 


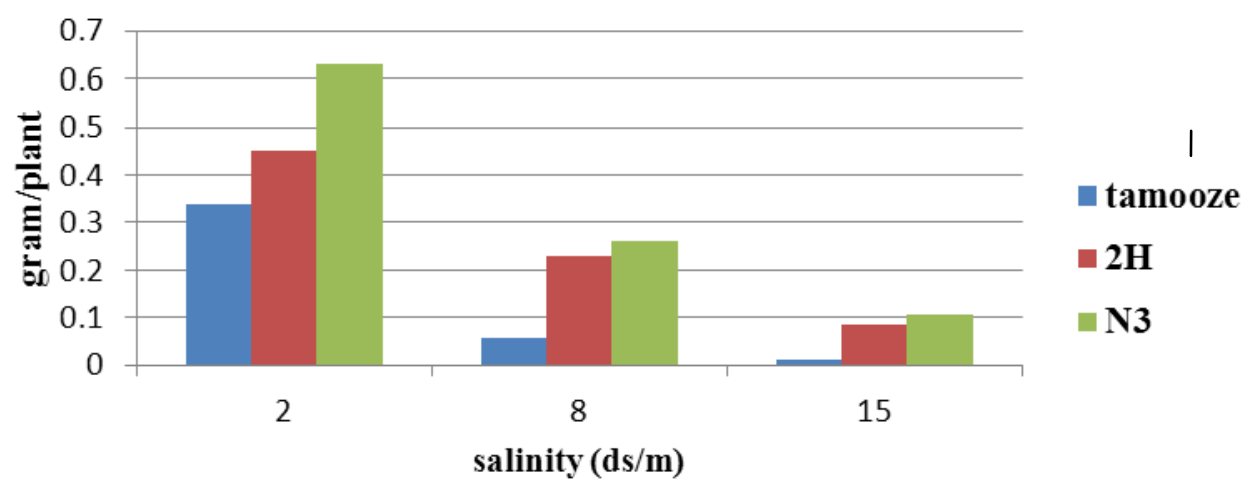

Figure 2. Root dry wight of selected genotypes of wheat under salinity condition

Results of analysis of variance for these data revealed that the interaction (salinity $\times$ genotypes) was significant, reflecting there were differences between the selected genotypes and local cultivar in their response to the salinity at all salt levels (Figures 1\&2) and (Plates 1\&2). The dry weight of these genotypes significantly decreased at 8 and $15 \mathrm{ds} / \mathrm{m}$, but there are significant differences between the selected genotypes ( $2 \mathrm{H} \mathrm{\& N} 3)$ and local cultivar (Tamooze- 2) in their dry weights reduction at each salt level. At $8,15 \mathrm{ds} / \mathrm{m}$ levels, the dry weights of shoots and roots of the selected genotypes were proximatilly similler, but they differed at $2 \mathrm{ds} / \mathrm{m}$. Also the results showed that the biggest reduction in dry weight was at $15 \mathrm{ds} / \mathrm{m}$ as compared with the 2 and $8 \mathrm{ds} / \mathrm{m}$, especially in the local cultivar (Tamooze-2). The results of shoots growth (Plate 1) revealed that the two selected genotypes were superior in germination percentage, in tillering, and leaves numbers especially at $8,15 \mathrm{ds} / \mathrm{m}$.
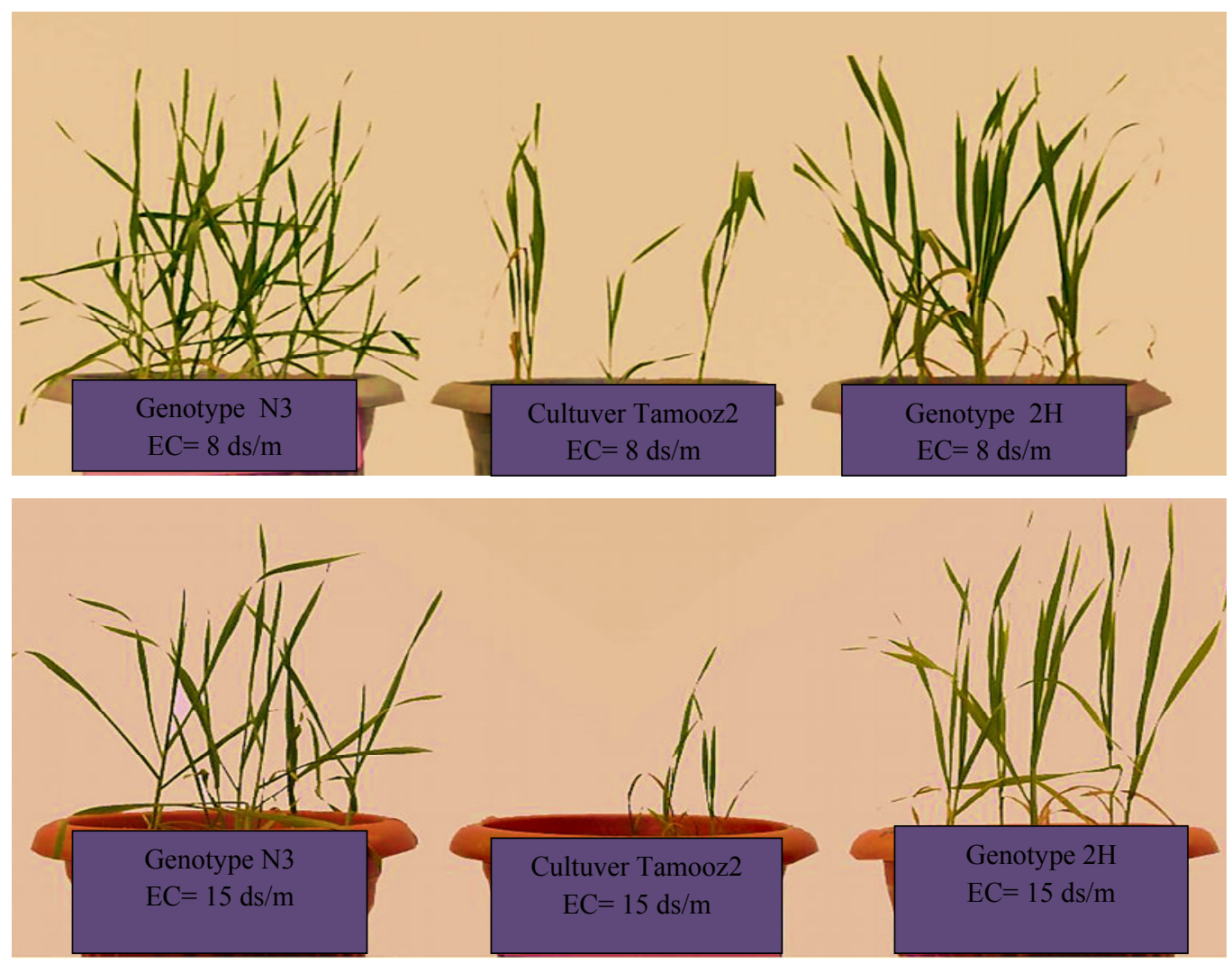

Plate 1. shoot growth of the selected wheat genotypes under salinity condition as compared with the local cultivar 

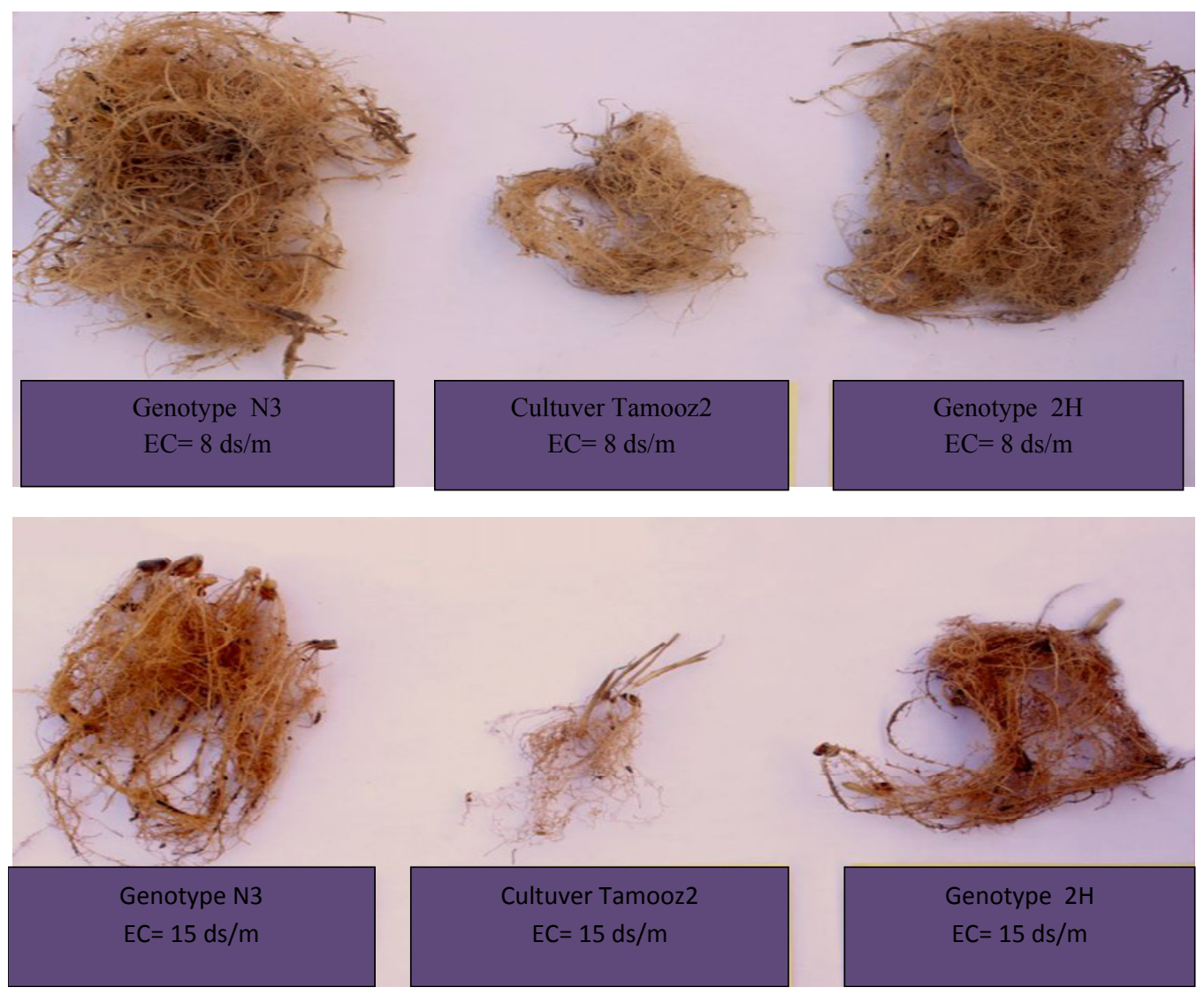

Plate 2. Root growth of the selected wheat genotypes under salinity condition as compared with the local cultivar

\section{$3.2 \mathrm{~K}^{+} / \mathrm{Na}^{+}$Ratio}

The data for $\mathrm{K}^{+} / \mathrm{Na}^{+}$ratio in upper leaves of all genotypes under salinity condition is presented in Figure 3 . The results show that there are significant differences between the selected genotypes and local cultivar in their $\mathrm{K}^{+} / \mathrm{Na}^{+}$ ratio at all salinity levels. $\mathrm{K}^{+} / \mathrm{Na}^{+}$ratio in upper leaves of these genotypes and local cultivar was significant decreased with increasing salinity, but there are significant variation between the selected genotypes and local cultivar in their $\mathrm{K}^{+} / \mathrm{Na}^{+}$ratio reduction at each salinity level (Figure 3). At $8 \& 15 \mathrm{ds} / \mathrm{m}$ levels, the selected genotypes had much higher $\mathrm{K}^{+} / \mathrm{Na}^{+}$ratio in their upper leaves than this of the local cultivar. Also the results showed that there are differences between the two selected genotypes in the $\mathrm{K}^{+} / \mathrm{Na}^{+}$ratio of their upper leaves at all salinity levels. At each salinity level the $\mathrm{N} 3$ genotype had higher $\mathrm{K}^{+} / \mathrm{Na}^{+}$ratio than the $2 \mathrm{H}$ genotype and local cultivar. At the highest salinity level, the $\mathrm{K}^{+} / \mathrm{Na}^{+}$in upper leaves was greater in the two selected genotypes than in the local cultivar (Figure 3).

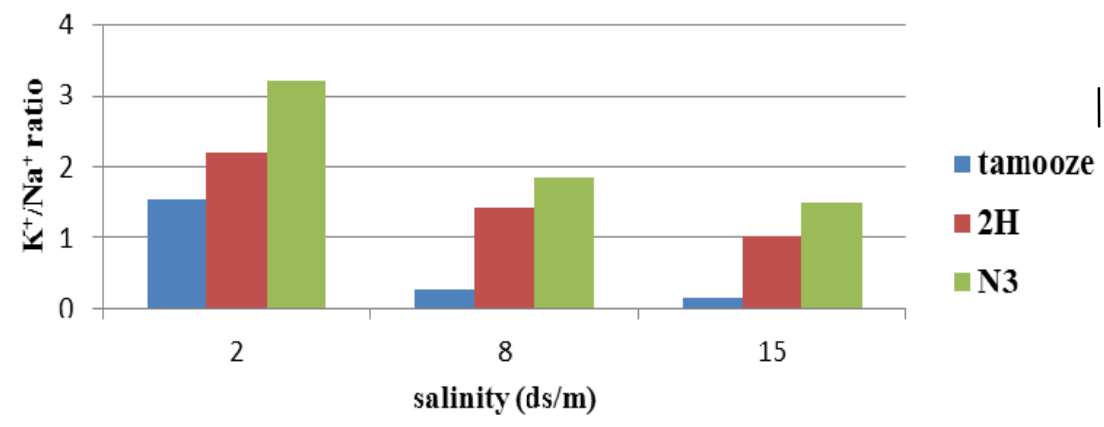

Figure $3 . \mathrm{K}^{+} \mathrm{Na}^{+}$ratio in upper leaves of selected genotypes of wheat under salinity condition 


\section{$3.3 \mathrm{Ca}^{+} / \mathrm{Na}^{+}$Ratio in Upper Leaves}

The data for $\mathrm{Ca}^{+} / \mathrm{Na}^{+}$ratio in upper leaves is presented in Figure 4, which showed that there are significant reductions in $\mathrm{Ca}^{+} / \mathrm{Na}^{+}$ratio in upper leaves under salinity conditions as compared with the control condition. All the genotypes had reduction in their $\mathrm{Ca}^{+} / \mathrm{Na}^{+}$ratio under salinity condition, but the reduction was more clear in local cultivar (Tamooze-2) as compared with the selected genotypes. At $8 \mathrm{ds} / \mathrm{m}$, the two selected genotypes were not differed in their $\mathrm{Ca}^{+} / \mathrm{Na}^{+}$ratio in upper leaves, while they differed significantly with the local cultivar. At 15 $\mathrm{ds} / \mathrm{m}$, there are significant variations between the genotypes and local cultivar in their $\mathrm{Ca}^{+} / \mathrm{Na}^{+}$ratio (Figure 4), but the selected genotypes had much higher $\mathrm{Ca}^{+} / \mathrm{Na}^{+}$ration than the local cultivar. This result reflect that maximum $\mathrm{Na}^{+}$accumulation was observed in local cultivar, whereas, it was lowest in the two selected genotypes under salinity conditions. Reverse, at the same salinity conditions, maximum $\mathrm{Ca}^{+}$contents in upper leaves were recorded in the two selected genotypes $(2 \mathrm{H} \& \mathrm{~N} 3)$. Whilst, the lowest contents were recorded in the local cultivar, therefore, maximum $\mathrm{Ca}^{+} / \mathrm{Na}^{+}$ratio was observed in these selected genotypes, especially at $15 \mathrm{ds} / \mathrm{m}$.

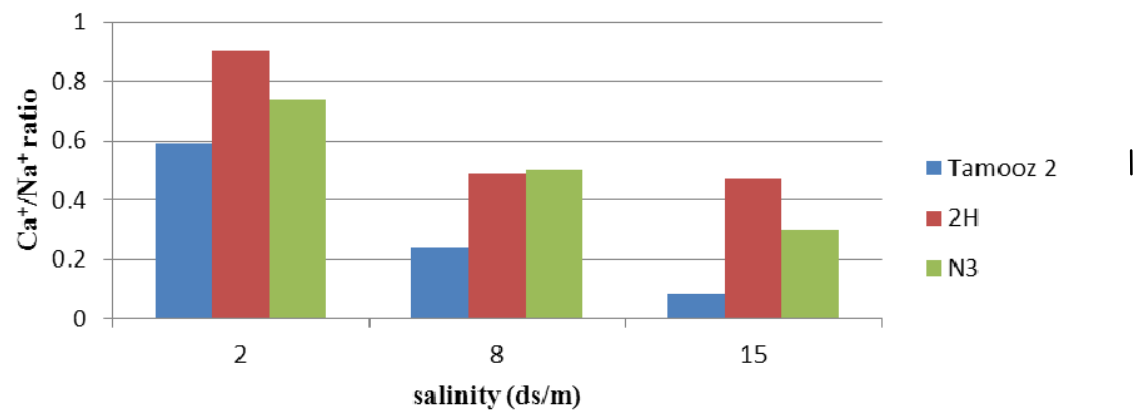

Figure $4 . \mathrm{Ca}^{+} / \mathrm{Na}^{+}$ratio in upper leaves of selected genotypes of wheat under salinity condition

\section{Discussion}

Under saline condition, due to excessive amounts of exchangeable $\mathrm{Na}^{+}$low $\mathrm{K}^{+} / \mathrm{Na}^{+}$ratio occur in the soil. Plants subjected to such environment, take up high amounts of $\mathrm{Na}^{+}$, whereas the uptake of $\mathrm{K}^{+}$is considerably reduced, and these increased with increasing salinity levels. These conditions were found in local cultivar (Figure 3), which showed that $\mathrm{K}^{+} / \mathrm{Na}^{+}$decreased with increasing salinity level. This revealed that $\mathrm{Na}^{+}$concentration in upper leaves highly increased and $\mathrm{K}^{+}$concentration highly decreased in the local cultivar with increasing salinity level as compared with those of the two selected genotypes, which their $\mathrm{Na}^{+}$concentration less increased and $\mathrm{K}^{+}$ concentration less decreased at each salinity level. There for the $\mathrm{K}^{+} / \mathrm{Na}^{+}$ratio of the two selected genotypes higher than this of the local cultivar (Figure 3). These conditions improved the growth of shoots and roots of the two selected genotypes under salinity condition as compared with the growth in local cultivar (Figure 1, 2 \& Plate 1,2). At each salt concentration the growth of the both characters of the two selected genotypes much higher than those of the local cultivar, this improvement more correlated with their $\mathrm{K}^{+} / \mathrm{Na}^{+}$ratio in upper leaves.

This result reflecting the fact that the high $\mathrm{K}^{+} / \mathrm{Na}^{+}$ratio in plant more correlated with the salt tolerance in this plant under salinity condition. The same conclusion are reported by Marschner (1995), Wenxue et al., (2003) and Munns et al. (2000) that they revealed reasonable amounts of both $\mathrm{K}^{+}$and $\mathrm{Ca}^{+}$are required to maintain the integrity and functioning of cell membranes, which are very important for plant growth under saline condition. This result showed that the salt tolerance of the selected genotypes associated with the maintenance of adequate $\mathrm{K}^{+}$in plant leaves tissue under salt stress which seems to be dependent upon selective $\mathrm{K}^{+}$uptake, selective cellular $\mathrm{K}^{+}$, and $\mathrm{Na}^{+}$ compartmentation and distribution in the shoots (Munns et al., 2000; Carden et al., 2003). Therefore, high $\mathrm{K}^{+} / \mathrm{Na}^{+}$ selectivity in plants under saline conditions has been suggested as an important selection criterion for tolerance (Corham et al., 1997; Ashraf, 2002; Wenxue et al., 2003). On the other hand, kafkafi (1984) concluded that roots of the salt tolerant Beta vulgaris had a greater affinity for $\mathrm{K}^{+}$relative to $\mathrm{Na}^{+}$than did the salt sensitive phaseolus vulgaris, nd this increased $\mathrm{K}^{+} / \mathrm{Na}^{+}$ration in the shoots. This conclusion agree with the result of this work, which showed that each salt concentration the $\mathrm{K}^{+} / \mathrm{Na}^{+}$ration in upper leaves of the selected genotypes $(\mathrm{N} 3,2 \mathrm{H})$ much higher than those of the local cultivar. Also Munns et al. (2000) reported that selection for salt tolerant genotypes of durm wheat were screened for low $\mathrm{Na}^{+}$concentration in their leaves and the associated enhanced $\mathrm{K}^{+} / \mathrm{Na}^{+}$discrimination. Also they reported there was wide genetic variation was found in $\mathrm{Na}^{+}$accumulation and $\mathrm{K}^{+} / \mathrm{Na}^{+}$discrimination, according to this, there are wide genetic variations also was found in salt tolerance among durm wheat genotypes. The results of this study were agreed with the above conclusion, which showed that selected genotypes with high $\mathrm{K}^{+} / \mathrm{Na}^{+}$ration were more salt tolerance than the local cultivar with low $\mathrm{K}^{+} / \mathrm{Na}^{+}$(Figures 1,2,3 \& Plates 1,2). These result indicated 
that $\mathrm{Na}^{+}$exclusion from upper leaves is important at high salinity level (Munns, 2005). Because this caused reduction in $\mathrm{Na}^{+}$and increased in important elements such as $\mathrm{K}^{+}, \mathrm{Ca}^{+}$and $\mathrm{Mg}^{+}$concentrations in upper leaves to prevent leaf injury and enhancing growth and yield production (Husain et al., 2003).

Also Munns (2005) reported in addition of lowering $\mathrm{Na}^{+}$accumulation in upper leaves, $\mathrm{K}^{+}$and organic solutes should accumulate in the cytoplasm and vaculles to balance the osmotic pressure in the leaves cells. They would be important for turgor maintenance of cells and for a metabolic protective, and so maintain growth at high salinity levels. Similarly, in soybean, lauchlia and wieneke (1979) found that the salt tolerant CV.'Lee "accumulated more $\mathrm{k}^{+}$ in its leaves than did the salt sensitive CV.'Jackson". Asimilar mechanism of ion uptake has also been observed in barley (Wenxue et al., 2003).

Calcium is also known to play a crucial role in maintaining the structural and functional integrity of plant membranes in addition to its considerable roles in cell wall stabilization, regulation of ion transport, selectivity, and activation of cell wall enzymes (Rengel, 1992; Marschner, 1995). These effects are very important for physiological processes in the leaves cells and also plant growth. However, the differences between the two selected genotypes and local cultivar in their shoots and roots growth (Figures 1,2 \& Plates 1,2) under salinity conditions refer to their difference in $\mathrm{Ca}^{+}$concentration in upper leaves. Therefore these differences caused variation between them in their responses to the salinity, which more correlated with $\mathrm{Ca}^{+2} / \mathrm{Na}^{+}$ratio of the upper leaves (Figure 4), and then their salt tolerance also more correlated with the high $\mathrm{Ca}^{+2} / \mathrm{Na}^{+}$ratio in their upper leaves. The low $\mathrm{Ca}^{+2} / \mathrm{Na}^{+}$ratio of a saline medium and also in plant leaves plays a significant role in growth inhibition in addition to causing significant changes in morphology and anatomy of plants (Cramer, 1992). On the other hand, Soussi et al. (2001) and Unno et al. (2002) reported that the maintenance of calcium transport and accumulation in plant tissue under salt stress is an important determinant of salinity tolerance. In most cases salt tolerance of a crop cultivar can be increased by an increasing in the $\mathrm{Ca}^{+2}$ concentrations in the upper leaves, which depend on its concentration in the saline growth medium and plant selectivity mechanism that controlled by genetic.

$\mathrm{Ca}^{+2}$ maintenance and $\mathrm{Na}^{+}$exclusion, which are related to salinity tolerance in most crop cultivars, were genetically controlled with additive major genetic components (Foolad, 1997) and the inherent genetic capability to maintain $\mathrm{Ca}^{+2}$ in tissue and to exclude $\mathrm{Na}^{+}$from shoots were highly heritable traits, suggesting $\mathrm{Ca}^{+2} / \mathrm{Na}^{+}$and $\mathrm{K}^{+} / \mathrm{Na}^{+}$ratios might be promising indicators for discriminating between salt tolerant and salt sensitive plants of many crops.

These results of the shoots and roots growth reflect the large improvement in salt tolerance obtained in the selected genotypes through plant breeding programs after exposure to $30 \mathrm{ds} / \mathrm{m}$ drainage water for six cycles of screening and selection. Similar improvement was obtained in some selected genotypes of wheat through these plant breeding programs (AL-Mishhadani, 2012; AL-Mishhadani et al., 2014). This improvement in salt tolerance in these selected genotypes may due to these genotypes were selected from F2-F7, which generations generally contain much wider range of genetic variation in salt tolerance. Very small numbers of plants are still surviving after exposure these genetic materials to the $30 \mathrm{ds} / \mathrm{m}$ drainage water for 6-8 weeks. This refer to salt tolerant genes are segregated in these plants, which exhibited salt tolerance character in these survived plants under saline conditions (gene $\times$ environment interaction) (Al-Mishhadani, 2012). Therefore, the salt tolerance is correlated with the number and kind of segregated salt tolerant genes that control the salt tolerance mechanisms and determine the degree of tolerance in plant (Munns, 2005). The superiority of selected genotypes in salt tolerance of the local cultivar (Plates 1\&2) may due to exposure the genetic materials to high salt concentration $(30 \mathrm{ds} / \mathrm{m})$. Similarly, AL-Mishhadani (2012) reported that selection at high salt concentration may be useful for identifying high salt tolerant progeny. Also the superiority of shoots growth (Plate 1 \& Figure 1) of these selected genotypes as compared with those of local cultivar may due to their superiority in roots growth (Plate $2 \&$ Figure 2) and in $\mathrm{K}^{+}$, $\mathrm{Ca}^{+2}$ concentrations in upper leaves.

Generally, these results concluded that the selected genotypes more salt tolerant than the local cultivar, the plant breeding programs were affective in improvement of salt tolerance in these selected genotypes, and $\mathrm{Ca}^{+2} / \mathrm{Na}^{+}$, $\mathrm{K}^{+} / \mathrm{Na}^{+}$ratios more correlated with the salt tolerance of these selected genotypes.

\section{Reference}

AL-Mishhadani, I. I. H. (2012). Breeding and selection of same lines of bread wheat for salt tolerance. Journal of Agricultural science and Technology, B2, 934-939.

AL-Mishhadani, I. I. H. (2014). Estimation of new wheat genotypes for salt tolerance which induced through plant breeding programs. J. of Agricultural Sci. and Technology, B4.

Ashraf, M. (2002). Salt tolerance of cotton: some new advances. Critical Reviews in Plant Sciences, 21(1), 1-30. http://dx.doi.org/10.1016/S0735-2689(02)80036-3 
Carden, D. E., Walker, D. J., Flowers, T. J., \& Miller, A. J. (2003). Single-cell measurements of the contributions of cytosolic $\mathrm{Na}^{+}$and $\mathrm{K}^{+}$to salt tolerance. Plant Physiology, 131(2), 676-683. http://dx.doi.org/10.1104/pp.011445

CRAMER, G. R. (1992). Kinetics of maize leaf elongation II. Responses of a Na-excluding cultivar and a $\mathrm{Na}$-including cultivar to varying $\mathrm{Na} / \mathrm{Ca}$ salinities. Journal of Experimental Botany, 43(6), 857-864.

Foolad, M. R. (1997). Genetic basis of physiological traits related to salt tolerance in tomato, Lycopersicon esculentum Mill. Plant Breeding, 116(1), 53-58. http://dx.doi.org/10.1111/j.1439-0523.1997.tb00974.x

Gorham, J., Bridges, J., Dubcovsky, J., Dvorak, J., Hollington, P. A., LUO, M. C., \& Khan, J. A. (1997). Genetic analysis and physiology of a trait for enhanced $\mathrm{K}+/ \mathrm{Na}+$ discrimination in wheat. New Phytologist, 137(1), 109-116. http://dx.doi.org/10.1046/j.1469-8137.1997.00825.x

Gorham, J., Jones, R. W., \& Bristol, A. (1990). Partial characterization of the trait for enhanced K+- Na+ discrimination in the D genome of wheat. Planta, 180(4), 590-597. http://dx.doi.org/10.1007/BF02411458

Husain, S., Munns, R., \& Condon, A. T. (2003). Effect of sodium exclusion trait on chlorophyll retention and growth of durum wheat in saline soil. Crop and Pasture Science, 54(6), 589-597. http://dx.doi.org/10.1071/AR03032

Kafkafi, U. (1984). Plant nutrition under saline conditions. In J. Shainberg (Ed.), Soil Salinity Under Irrigation, Processes and Management (pp. 319-338). Berlin: Springer.

Lauchli, A., \& Wieneke, J. (1979). Studies on growth and distribution of $\mathrm{Na}^{+}, \mathrm{K}^{+}$and $\mathrm{Cl}^{-1}$ in soybean varieties differing in salt tolerance. Z. Pflanzenen, Bodenk, 142, 3-13. http://dx.doi.org/10.1002/jpln.19791420103

Marschner, H. (1995). Mineral Nutrition of Higher Plants. Acad. Pr., London (1995).

Mass, E. V., \& Poss J. A. (1989). salt sensitivity of cowpea at various growth stages. Irri Sci. 10, 313-320.

Mass, E. V., \& Tiller, C. M. (1994). Development in salt stressed wheat. Crop Sci., 34, 1594-1603. http://dx.doi.org/10.2135/cropsci1994.0011183X003400060032x

Munns, R. (2005). Gene and salt tolerance: bringing them to gather. New Phytologist, 167, 645-665. http://dx.doi.org/10.1111/j.1469-8137.2005.01487.x

Munns, R., \& James, R. A. (2003). Screening methods for salt tolerance: a case study with tetraploid wheat. Plant and Soil, 253, 201-218. http://dx.doi.org/10.1023/A:1024553303144

Munns, R., Hare, R. A., James, R. A., \& Rebetzke, G. J. (2000). Genetic variation for salt tolerance of durm wheat. Aust. J. Agri. Res., 51, 69-74. http://dx.doi.org/10.1071/AR99057

Munns, R., James, R. A., \& Läuchli, A. (2006). Approaches to increasing the salt tolerance of wheat and other cereals. Journal of Experimental Botany, 57(5), 1025-1043. http://dx.doi.org/10.1093/jxb/erj100

Pitman, M. G., \& Lauchli, A. (2002). Global impact of salinity and agricultural ecosysteme. In A. Lauchli, \& U. Luttge (Eds.), Salinity: Environment-plant-molecules. the Netherlands: Dordrechr.

Rengel, Z. (1992). The role of calcium in salt toxicity. Plant Cell Environ, 15, 625-632. http://dx.doi.org/10.1111/j.1365-3040.1992.tb01004.x

Soussi, M., Ocana, A., \& Lluch, C. G. (2001). Nitrogen fixation and ion accumulation in two chickpea cultivars under salt stress. Agricoltura mediterranea, 131, 1-8.

Unno, H., Maeda, Y., Yamamoto, S., Okamoto, M., \& Takenaga, H. (2002). Relationship between salt tolerance and $\mathrm{Ca} 2+$ retention among plant species. Japanese Journal of Soil Science and Plant Nutrition, 715-718.

Wenxue, W., Bilsborrow, P. E., Hooley, P., Fincham, D., Lombi, E., \& Forster, B. P. (2003). Salinity induced difference in growth, ion distribution and partitioning in barley between the cultivar may Thorpe and its derived mutant golden promise. Plant Soil, 250, 183-191. http://dx.doi.org/10.1023/A:1022832107999

Zohary, M. (1973). Geobotanical foundation of the Middle East, 2 Vols Amsterdam. Stuttgart, 33-44.

\section{Copyrights}

Copyright for this article is retained by the author(s), with first publication rights granted to the journal.

This is an open-access article distributed under the terms and conditions of the Creative Commons Attribution license (http://creativecommons.org/licenses/by/3.0/). 